American University Washington College of Law Digital Commons @ American University Washington College of Law

8-1-2012

\title{
How Well Does the G20 Reflect African Interests and Priorities?: Some Thoughts Following the Los Cabos, Mexico Summit
}

Daniel Bradlow

American University Washington College of Law, bradlow@wcl.american.edu

Follow this and additional works at: http://digitalcommons.wcl.american.edu/fac_works_papers Part of the Law Commons

\section{Recommended Citation}

Bradlow, Daniel David, How Well Does the G20 Reflect African Interests and Priorities?: Some Thoughts Following the Los Cabos, Mexico Summit (2012). SAFPI Policy Brief \#6, August 2012.

This Article is brought to you for free and open access by the Works at Digital Commons @ American University Washington College of Law. It has been accepted for inclusion in Working Papers by an authorized administrator of Digital Commons @ American University Washington College of Law. For more information, please contact fbrown@wcl.american.edu. 


\section{How well does the $\mathbf{G} 20$ reflect African interests and priorities? Some thoughts following the Los Cabos, Mexico summit}

The leaders of the G20 countries have now held seven summits - enough to begin critically evaluating how well the G20 serves the interest of specific sub-parts of the international community. The purpose of this policy brief is to assess how well the $\mathrm{G} 20$ responds to African interests. It is divided into three parts. The first is a brief description of the most recent summit, held on June 18-19, 2012 in Los Cabos, Mexico. The second part is a brief discussion of the criteria that will be used in this evaluation. The third part is an assessment of the G20 against these criteria.

\section{The Los Cabos summit}

The G20 summit is the culmination of a busy schedule of meetings of senior policy makers and technical experts. The participants in these meetings include, in addition to the representatives of the $\mathrm{G} 20$ states themselves, officials from international organizations such as the IMF, the World Bank, the regional development banks, the FSB, OECD, ILO, UNCTAD, WTO, and UNDP. Representatives of regional organizations, such as the $A U$ and NEPAD, are present at the summit. The purpose of these meetings is to follow up on the decisions and requests of the $\mathrm{G} 20$ leaders, promote cooperation between the participants of the G20 process on particular issues, and to help shape the summit discussions and communiqué.

So far, the host country for each year's summit has served as the chair of the G20 during that year, even though the individual G20 working groups, panels and task forces will have their own chairs. The host state is responsible for organizing and chairing the summit's preparatory meetings and the summit itself. This allows the host country to influence both the G20's agenda for that year and its future work programme. For example, Mexico as the 2012 host nation, focused attention on green growth and job creation.

Since the G20 does not have a permanent secretariat, the participating international organizations usually assume responsibility for preparing the background studies and policy proposals for the leaders of the G20 and may play a role in implementing their decisions. For example, the FSB and the IMF coordinate many of the studies on financial regulatory issues and the IMF serves as the leading independent assessor in the mutual assessment program that the G20 countries are implementing. These organizations also help transmit G20 initiatives, for example those relating to financial sector regulation, to the other states in the global system.

The final point to note about the evolving G20 process is the growing range of affiliated meetings held in conjunction with the G20 process. In the case of the Los Cabos summit, Mexico organized meetings of business leaders, labour, youth, think tanks, and civil society from the $\mathrm{G} 20$ countries. These meetings may result in reports which can feed into the $\mathrm{G} 20$ process.

\section{The results of Los Cabos}

The "Los Cabos Leadership Declaration", the communiqué issued by the leaders at the end of the summit, makes clear that, although the 2012 G20 summit was dominated by the Eurozone crisis, the leaders discussed other matters. 
It is divided into the following sections: supporting economic stabilization and the global recovery; employment and social protection; trade; strengthening the international financial architecture; reforming the financial sector and fostering financial inclusion; enhancing food security and addressing commodity price volatility; meeting the challenges of development; promoting longer term prosperity through inclusive green growth; and intensifying the fight against corruption.

In each section the leaders explain why they think the issue is important and they commit, or often recommit, themselves to certain objectives. However, they do not specify what actions they will take to reach these objectives. They also request different actors, such as their ministers of finance or specific groups of international organizations, to undertake certain studies or prepare particular reports.

The leaders also issued a "Los Cabos Growth and Jobs Action Plan" in which they promise to undertake a range of country and group specific measures to protect the integrity of the Eurozone, promote fiscal sustainability, price stability, and job creation. They also released a document containing the relevant policy commitments of each G20 member state. Most of the participating states, however, have previously committed themselves to these actions in earlier G20 meetings and/or in domestic policy documents.

At Los Cabos, the participants also re-asserted their determination to implement the "Accountability Assessment Framework", which creates a process of peer review evaluations of each participating state's implementation of the G20's "strong, sustainable and balanced" growth framework. The first report on this mutual assessment process, in which the IMF assists, was issued at Los Cabos.
One noteworthy action announced at the summit was that a group of countries, including all the BRICS countries, agreed to lend new funds to the IMF for use in future IMF operations, including in the Eurozone. Many of these countries are hoping that their contributions will help accelerate IMF governance reform.

The progress report of the G20 Development Working Group presented at Los Cabos is of particular interest to Africa. This report reaffirms the G20's commitment to promoting such international objectives as the Millenium Development Goals and development effectiveness. In addition, the report discusses, in some detail, implementation of the Working Group's priorities - infrastructure, food security and inclusive green growth. For example, the document stipulates in paragraph 14 that "incorporating social and environmental costs and benefits into economic decision making" is "critical" to inclusive green growth". In regard, to infrastructure it states in paragraph 16 that its approach to infrastructure should seek "synergies" with inclusive green growth and the Group's development pillars - food security, human resource development, trade, private investment with job creation, growth with resilience, financial inclusion, domestic resource mobilization, and knowledge sharing. It adds, in the same paragraph, that "adequately designed infrastructure investments offer opportunities for triple wins: economic growth, social inclusion and greater environmental sustainability". In regard to food security, the report, in paragraph 27, highlights the importance of agricultural research and welcomes the work that is being done by other international bodies. It also encourages, in paragraph 31, all countries to support the "Principles for Responsible Agricultural Investment" and the "Voluntary Guidelines on the Governance of Tenure of Land, Fisheries and Forest in the Context of National Food Security". 


\section{Criteria for evaluating the $\mathbf{G 2 0}$}

The criteria for evaluating how well the G20 serves African interests needs to be based on an understanding of both the functions of the G20 and of "African interests".

\section{The functions of the $\mathbf{G 2 0}$}

The G20 performs three functions. First, it is a crisis manager. In this capacity it is focused on forging agreement on the actions that the participants, individually and collectively, must take in order to try and resolve the crisis.

Second, the G20 is an actor in global economic governance. It is the setting in which the major economies meet with the major international institutions - the IMF, the World Bank, the WTO, the UN - to discuss the key economic challenges facing the international community. The G20, therefore, enables the relevant policy makers and technical experts from the participating countries and international organizations to meet and seek to develop common understandings and approaches on particular issues of global importance.

Third, the G20 is a communicator. It helps to promote international global awareness of the challenges facing the global community and the approach that the most powerful countries are considering for dealing with these challenges.

\section{Defining "African interests"}

A continent with many diverse countries does not have one undifferentiated set of interests. Nevertheless, all sub-Saharan African countries do have some common concerns that can be considered to be "African interests" for this purpose. They all would benefit from economic policies and practices, at the global and national level, that are inclusive, in the sense that they allow all stakeholders, including the weakest nations, the poorest individuals, and the smallest companies to share in their benefits. They also share an interest in promoting balanced economic growth and development that is environmentally sustainable. Finally, all African nations seek effective global economic governance arrangements in which all stakeholders are able to participate.

Given these functions, there are four tests that can be used to determine how well the G20 responds to African interests:

- How well does the G20 address the challenges created by the lack of inclusiveness - that is poverty, inequality, unemployment, and the inability of citizens to engage in national affairs?

- How effectively does the G20 respond to the difficult environmental challenges that Africa is facing?

- How effectively does the G20 support Africa's ability to mobilize resources to finance its development?

- Does the G20 promote global economic governance arrangements that allow for meaningful participation by all stakeholders, and that are transparent and accountable?

\section{Evaluating the $\mathbf{G 2 0}$}

\section{Addressing inclusion}

At a rhetorical level the $\mathrm{G} 20$ can claim some success in making development more inclusive. The Los Cabos communiqués talks about the importance of inclusive green growth, job creation, social security and financial inclusion. However, the documents do not define what "inclusion" means for the G20 nor do they provide any guidance on the strategy for achieving it. This is particularly important given that there is no general consensus on how inclusion can be most effectively incorporated into the way in which 
specific development policies are made and projects are selected, prepared, implemented, and operated.

The G20 seems to address this issue indirectly through its institutional arrangements and work programme. For example, the creation of the Development Working Group, in part, is an effort to make sure that the concerns of developing countries are included in global economic governance. In addition, the $\mathrm{G} 20$ has created a group to work on financial inclusion and has asked the Basel Committee on Banking Supervision to study the impact of specific financial regulatory reforms on emerging markets and developing countries. It has also taken actions that are designed to reduce the volatility in commodity markets and to promote food security The $\mathrm{G} 20$ has also played a role in seeking to reform the governance structures of the multilateral development banks and the IMF and in ensuring that they have sufficient resources to fulfil their mandates, which, at least to some extent, deal with the challenge of exclusion at the level of the global economic system. These measures are all still in the process of being implemented and so it is too soon to judge their efficacy.

\section{Environmental challenges}

Africa is facing a number of important environmental challenges - for example, climate change, water shortages - that have the potential to constrain African efforts to deal with the problems of food security, infrastructure, urbanization, and job creation. The G20 does address these issues in its Los Cabos communiqué, where it discusses issues like green growth and food security. In addition, the Development Working Group in its report emphasizes the importance of incorporating environmental considerations into economic decision making, and infrastructure project planning, construction, and operation. However, neither document evidences any attempt by the G20 to carefully consider how this should be done. There is no discussion in these documents on how to manage the complex trade-offs between maximizing economic benefits and mitigating the environmental and social costs that are likely to be required in regard to inclusive green growth, sustainable infrastructure, and environmental sensitive economic decision making. This is particularly troubling because there is clear evidence that these trade-offs exist, are complicated, capable of generating intense and sustained conflicts, and are seldom effectively resolved.

\section{Resource mobilization}

Africa needs additional resources to finance its economic development. While the G20 is not a fund-raising body, it does pay attention to this issue. For example, it has expressed an interest in promoting more inclusive finance and one task assigned to its High Level Panel on Infrastructure was to identify innovative ways of financing infrastructure projects. In addition, the Development Working Group includes domestic resource mobilization as one of its development "pillars". However, the G20 appears to view its function in this regard to be to highlight the issue rather to resolve it. Its documents provide very little information on how the G20 plans to address the challenges that developing countries, particularly African countries, face in mobilizing resources. It praises a number of existing initiatives but does not propose any new ones. 


\section{Global Economic Governance}

African countries are under-represented in the G20. Thus, they have a strong interest in G20 undertaking efforts to promote greater participation in its process, and greater accountability to those affected by its decisions and actions. To date, the $\mathrm{G} 20$ has not responded effectively to these interests.

One reason for this is the composition of the G20. The participants in the $\mathrm{G} 20$ process are a selfselected group of countries, together with those other inter-governmental and non-governmental participants that the members themselves choose to invite. These participants have no formal obligation to consult with other stakeholders about their agenda, work plan or decisions. The fact that the level of consultation is at the discretion of the various participants does not, however, mean that the participants do not consult with others. For example, South Africa does consult with other African countries through the C10, a grouping of African Ministers of Finance and central bank governors. In addition, the amount of consultation undertaken by each summit chair will vary. For example, the Mexicans organized meetings with business leaders, labour leaders, think tanks and researchers, youth and civil society from G20 countries prior to Los Cabos. However, the invitees to these meetings attended in their personal capacities and without any mandate from broader groupings in their own countries. These meetings were arranged at the discretion of the Mexicans and there is no guarantee that the Russians, the next G20 chair, will be as participatory in their approach. Moreover, there is no formal process through which interested stakeholders, who were not invited to these meetings, can submit information to these meetings or to the formal meetings in the G20 process.

There is also no requirement that the $\mathrm{G} 20$ chair or other participants in $\mathrm{G} 20$ meetings report back to interested parties on the content of these meetings. The latter group are reduced to learning about the work of the $\mathrm{G} 20$ and the content of these meetings from the G20 documents which are publicly available on its website, the content of which is determined by the G20 chair for that year. The media also play an important role in this regard.

Finally, it is difficult for interested stakeholders to hold the G20 accountable. While individual leaders and their governments may have to answer for their actions in the G20 through the electoral processes in each member country, there are no mechanisms through which interested persons can hold the G20 participants collectively or individually accountable for their failure to address particular issues, their approach to those issues that they do address, or for their failure to consult or to report back to their various stakeholders. One example of the problems that this can create is that the Basel Committee on Banking Supervision, because it did not consult fully with all states and regulatory authorities that were not members of the Committee, failed to fully appreciate the impact of its imposed new capital adequacy standards on developing countries. As a result, the $\mathrm{G} 20$ has been forced to request a new study to review this matter.

\section{Conclusion}

The G20 has now been operating at a summit level for long enough that it is possible to begin critically assessing its performance. This paper is a first attempt to evaluate how responsive the G20 is to African interests. It identifies three functions that the $\mathrm{G} 20$ performs, and defines a set of African interests to which the G20 could be expected to respond. The paper then posits four tests for determining the responsiveness to African interests. It finds that the $\mathrm{G} 20$ does address African interests in its formal documents. However, this is often at a general level and without either making commitments to specific 


\section{SAFPI Policy Brief No 6}

actions or providing the specific details that could assist African countries and their partners in formulating and implementing their own strategies for addressing these interests. This suggests that the G20 performs its awareness promoting function more effectively that its global economic governance function. It would also seem to be more effective at addressing the acute crises experienced by the Northern countries than the slower more endemic crises that afflict Africa.

* Daniel Bradlow is SARCHI Professor of International Development Law and African Economic Relations, University of Pretoria and Professor of Law, American University Washington College of Law. He is also the co-coordinator of the Global Economic Governance Africa project, a joint project of the International Development Law Unit, University of Pretoria and the South African Institute for International Affairs. 